\title{
Assessment of toxic heavy metal levels in black tiger shrimp, Peneaus monodon cultured in the northwestern province of Sri Lanka
}

\author{
S.P.S.D. SENADHEERA ${ }^{1 *}$ AND K.A.S. PATHIRATNE ${ }^{2}$ \\ 'Post Harvest Technology Division, National Aquatic Resources \\ Research and Development Agency, Crow Island, Colombo 15, Sri \\ Lanka. \\ ${ }^{2}$ Department of Chemistry, University of Kelaniya, Kelaniya, Sri \\ Lanka.
}

*Corresponding author [Present address: National Institute of Fisheries and Nautical Engineering, Crow Island, Colombo 15, Sri Lanka (E-mail: shyamalie_s@hotmail.com)]

\begin{abstract}
The aim of this study was to determine the levels of three toxic heavy metals; lead, cadmium and chromium in the muscle tissue of the shrimp, Penaeus monodon cultured in the North Western Province (NWP) of Sri Lanka to examine whether the levels of these toxic heavy metals exceed the permissible/guide levels stipulated in the established quality guidelines for human consumption. Lead, cadmium and chromium concentrations in the muscle tissue of the shrimp, $P$. monodon from selected farms that fed from four selected water sources (Puttalam lagoon, Dutch canal, Mundal lagoon and Gembarandiya lagoon) in the NWP were determined by atomic absorption spectrophotometry using standard analytical procedures.

The levels (Mean \pm SEM) of lead, chromium and cadmium in the muscle tissue of the shrimp (in $\mu \mathrm{g} \mathrm{g}^{-1}$ wet weight) were $0.096 \pm 0.024$, $0.200 \pm 0.004$ and $0.057 \pm 0.004$ respectively. Even though water source-wise differences could not be detected in relation to the cadmium levels, lead and chromium levels in the shrimp tissue cultured in water from the four water sources were significantly different from each other. However, none of these metals in the shrimp tissue exceeded the maximum permissible levels or the guide levels established by the statutory authorities under fish import/export regulations. The present study indicates that there is no risk of intake of these metals from the shrimp, P. monodon cultured in the NWP of Sri Lanka as the current residue levels in the muscle tissue of the shrimp are within the safety permissible levels for human consumption.
\end{abstract}




\section{Introduction}

Human beings are exposed to metallic elements through both food and water. Fish and fishery products play a major role in heavy metal uptake to the human body tissues (Storelli and Marcotrigiano 1999). Some trace elements such as iron, molybdenum, manganese, cobalt, copper, and zinc, which have been linked to human growth, development and reproduction, are essential to human life (Garbarino et al. 1995). Biological anomalies arise when they are depleted or removed. Even these metals, however, can become toxic or aesthetically undesirable when their concentrations are too great. Several heavy me als, such as cadmium, lead, and mercury, are highly toxic at relatively low zoncentrations. These metals can accumulate in body tissues over long periods of time, and are nonessential for human health (Garbarino et al. 1995; Zhou et al. 2001). Heavy metals that may contaminate different food cause serious health hazards depending on their relative levels (AbouArab et al. 1996).

In Sri Lanka, export of cultured shrimp, Penaeus monodon plays a significant role in earning foreign exchange to the country's economy. The cultured shrimp are exported to the developed countries such as Japan, USA and the European Union where stringent quality guidelines are-strictly adopted to imported fish and fishery products. P. monodon is a benthic feeder and it is also considered a carnivore, detritovore and an omnivore depending on the availability of type of food (Solis 1988; Rao 1998). As such, there is a high tendency for accumulation of heavy metals present in the environment, in the body tissues of shrimp through the food chains. Even though, the aquatic environment of Sri Lanka where shrimp farming is extensively carried out is said to be deteriorated with the self pollution of the farms (Corea et al. 1998) and with the increasing urbanization, no scientific study has yet been carried out to assess the residue levels of toxic trace metals especially $\mathrm{Pb}, \mathrm{Cd}$ and $\mathrm{Cr}$ in the cultured shrimp and their immediate environment. Further, there is a need to generate a database on the residue levels of these tc xic elements to cater to the needs of the national quality assurance programs. Therefore, the objective of the present study was to determine the residue levels of three selected trace metals, i.e., lead, cadmium and chromium in $P$. monodon cultured in the North Western Province (NWP) of Sri Lanka to ensure product quality in both economic wise and sanitary point of view.

\section{Materials and methods}

\section{Sampling of shrimp}

Three shrimp farms fed from each of the four water sources (Puttalam lagoon, Mundal lagoon, Dutch canal and Gembarandiya lagoion) were selected for the study. Shrimp samples were collected in 2001 at harvest 
or at the end of ibe culture cycle of each farm studied. Three shrimp samples each containing 10 individuals were taken from each farm and were transported to the laboratory in polyethylene bags under chilled conditions. The shrimp were immediately cleaned with de-ionized water and their total lengths and weights were recorded. The total lengths and the weights of the shrimp collected ranged between $13.0-18.2 \mathrm{~cm}$ and 15.49- $38.49 \mathrm{~g}$ respectively. The cleaned shrimp were kept in a freezer at $-20^{\circ} \mathrm{C}$ in polyethylene bags until analysis.

\section{Processing of sal ples before digestion}

The thaved shrimp were de-headed and the shells were removed using a plastic scalpel to avoid metal contamination. The flesh of each shrimp sample was homogenized using an Ultra turax homogenizer and the homogenate was weighed using an electronic balance. Then, the pre-weighed sample was kept in a pre acid washed evaporating dish and dried in an oven at $70^{\circ} \mathrm{C}$ for $>48 \mathrm{~h}$ to a constant weight. The dried sample was then ground into a fine powder using a porcelain mortar and pestle and kept in a glass container in a refrigerator at $4^{\circ} \mathrm{C}$ until digestion.

\section{Digestion of shrimp tissue}

For the determination of cadmium, chromium \& lead, the shrimp tissue was digested using a dry ashing procedure (Jorhem 1993). A quantity of $3 \mathrm{~g}$ of the dried sample was accurately weighed into a $100 \mathrm{~cm}^{3}$ pyrex beaker and kept in the muffle furnace at $200^{\circ} \mathrm{C}$. After 2 hours, the temperature was increased at the rate of $50^{\circ} \mathrm{C} / \mathrm{h}$ upt $540^{\circ} \mathrm{C}$ and kept overnight. The samples were then cooled and treated with $5 \mathrm{ml}$ of $6 \mathrm{M}$ hydrochloric acid and evaporated to dryness on a hot plate. Two reagent blanks were similarly processed and each sample was analyzed in duplicate.

\section{Analysis of lead, cadmium \& chromium}

The dry ashed shrimp tissue (in $100 \mathrm{ml}$ beaker) was re-dissolved in 5 $\mathrm{ml}$ of $0.1 \mathrm{M}$ nitric acid (analytical grade) just before aspirating into the air acetylene flame of the Atomic Absorption Spectrophotometer (GBC Aventra) for measurements of the three elements. All the data were computed on $\mu \mathrm{g} / \mathrm{g}$ fresh weight basis. The recovery tests were performed by standard additions to the homogenized sample before digestion. When reporting the results, percentage recoveries for the three elements were taken into consideration.

\section{Statistical Analysis}

Data are presented as mean \pm standard error of mean (SEM) of the replicates. Differences among the three metal levels in the muscle tissue of the shrimp and the differences of the levels of each metal in shrimp among the four water sources were determined by one way analysis of variance (ANOVA). Log transformed data were used for all the statistical analyses. 
Where differences were significant, mean values were compared by Tukey's test. The data were statistically analyzed using the MINITAB version 10.2 computer software package.

\section{Results and Discussion}

Metal-wise comparison

Comparisons among the levels of the three metals in the shrimp cultured in the twelve farms are presented in Table 1. Metal-wise comparisons indicated that the levels of chromium in the muscle tissue of the shrimp cultured in two third of the farms were significantly higher than those of the other two metal levels. The chromium contents in the muscle tissue of the shrimp from rest of the farms were not significantly different from that of the levels of lead. In the shrimp cultured in all the farms studied, the cadmium levels were significantly lower than that of chromium (Table 1).

Table 1. The lead, chromium and cadmium levels in tiger shrimp, Penaeus monodon cultured in twelve farms of the North Western Province, Sri Lanka.

\begin{tabular}{lccc}
\hline Farm & \multicolumn{3}{c}{ Metal level $\left(\mu g g^{-1}\right.$ wet weight $)$} \\
\cline { 2 - 4 } & \multicolumn{1}{c}{$\mathrm{Pb}$} & $\mathrm{Cr}$ & $\mathrm{Cd}$ \\
\hline P1 & $0.031^{\mathrm{a}} \pm 0.003$ & $0.091^{\mathrm{b}} \pm 0.021$ & $0.035^{\mathrm{a}} \pm 0.010$ \\
P2 & $0.051^{\mathrm{a}} \pm 0.010$ & $0.120^{\mathrm{b}} \pm 0.009$ & $0.068^{\mathrm{a}} \pm 0.005$ \\
P3 & $0.036^{\mathrm{a}} \pm 0.007$ & $0.110^{\mathrm{b}} \pm 0.006$ & $0.032^{\mathrm{a}} \pm 0.008$ \\
M1 & $0.110^{\mathrm{ab}} \pm 0.031$ & $0.140^{\mathrm{b}} \pm 0.008$ & $0.049^{\mathrm{a}} \pm 0.003$ \\
M2 & $0.064^{\mathrm{a}} \pm 0.010$ & $0.120^{\mathrm{b}} \pm 0.013$ & $0.053^{\mathrm{a}} \pm 0.004$ \\
M3 & $0.076^{\mathrm{b}} \pm 0.004$ & $0.110^{\mathrm{c}} \pm 0.005$ & $0.054^{\mathrm{a}} \pm 0.005$ \\
G1 & $0.086^{\mathrm{ab}} \pm 0.023$ & $0.160^{\mathrm{b}} \pm 0.023$ & $0.045^{\mathrm{a}} \pm 0.004$ \\
G2 & $0.074^{\mathrm{a}} \pm 0.008$ & $0.160^{\mathrm{b}} \pm 0.007$ & $0.066^{\mathrm{a}} \pm 0.005$ \\
G3 & $0.250^{\mathrm{b}} \pm 0.041$ & $0.280^{\mathrm{b}} \pm 0.066$ & $0.061^{\mathrm{a}} \pm 0.013$ \\
D1 & $0.100^{\mathrm{b}} \pm 0.012$ & $0.140^{\mathrm{b}} \pm 0.021$ & $0.027^{\mathrm{a}} \pm 0.002$ \\
D2 & $0.083^{\mathrm{a}} \pm 0.003$ & $0.190^{\mathrm{b}} \pm 0.004$ & $0.074^{\mathrm{a}} \pm 0.010$ \\
D3 & $0.110^{\mathrm{b}} \pm 0.017$ & $0.200^{\mathrm{c}} \pm 0.019$ & $0.039^{\mathrm{a}} \pm 0.004$ \\
\hline
\end{tabular}

Results are presented as mean \pm standard error of the mean $(n=30)$. For each row, means not followed by the same manuscript are not significantly different from each other (ANOVA, Tukey's test, $\mathrm{p}<0.05$ ). P1, P2 and P3 are farms fed from Puttalam lagoon; M1, M2 and M3 are farms fed from Mundal lagoon; G1, G2 and G3 are farms fed from Gembarandiya lagoon; D1, D2 and D3 are farms fed from Dutch canal. 
Water source-wise comparison

Variation of the metal levels in shrimp cultured in water from the four water sources is presented in Figure 1. The levels of lead in the shrimp cultured in the farms fed from Puttalam lagoon were significantly lower than those of the farms fed from the other three water sources. The levels of chromium in the shrimp tissue cultured in the farms fed from Puttalam lagoon and Mundal lagoon were significantly lower than those of the farms fed from Gembarandiya lagoon and the Dutch canal. This may be attributed to comparatively low population density and less industrial açtivities carried out in the associated regions of the Puttalam lagoon and the Mundal lagoon compared to the areas connecting to other two water sources. However, the levels of cadmiur: in shrimp tissue cultured in the farms fed from the four water sources we!e not significantly different from each other (Figure 1).

Overall residue levels in the muscle tissue of the shrimp

Table 2 presents the overall residue levels of lead, chromium and cadmium in the n uscle tissue of the shrimp cultured in selected shrimp farms of the NWP during one particular culture cycle in 2001. The maximum permissible levels (Anon. 2001) and the guide levels (Anon. 1996) for shellfish and finfish enforced by the European 'Union (EU) and the Food and Drug Administration (FDA), USA are also given in Table 2. The study indicated that the residue levels of the three metals were well below the maximum permissible levels and the guide levels enforced by the above authorities. Of the three metals selected for the study, chromium was the dominant metal accumulated in the shrimp tissue and cadmium was the metal that was recorded in comparatively low levels. In most occasions, the magnitude of the metals in the shrimp tissue was in the order, $\mathrm{Cr}>\mathrm{Pb}>\mathrm{Cd}$. Heiny and Tate (1.997) pointed out that the concentrations of metal in fish are related to the concentrations of metals in ingested food, water and sediments along with the rates of bioaccumulation and depuration, and these factors differ for different metals and the different fish species.

The levels of lead in the muscle tissue of $P$. monodon ranged from 0.002 to $0.330 \mu \mathrm{g} \mathrm{g}^{-1}$ wet weight. These values were lower than the specified limits for lead in crustaceans: $0.5 \mu \mathrm{g} \mathrm{g}^{-1}$ wet weight established by the European Union (Anon. 2001). Even though the upper limit of the residue level of lead was close to the maximum permissible level of the EU standards, that limit was reached only by $3 \%$ of the total shrimp samples analyzed. However, the mean lead levels were far below the FDA guide level for lead in crustaceans, $1.5 \mu \mathrm{g} \mathrm{g}^{-1}$ wet weight and in Molluscan bivalves, 1.7 $\mu \mathrm{g} \mathrm{g}^{-1}$ wet weight (Anon. 1996). 
(i) Lead

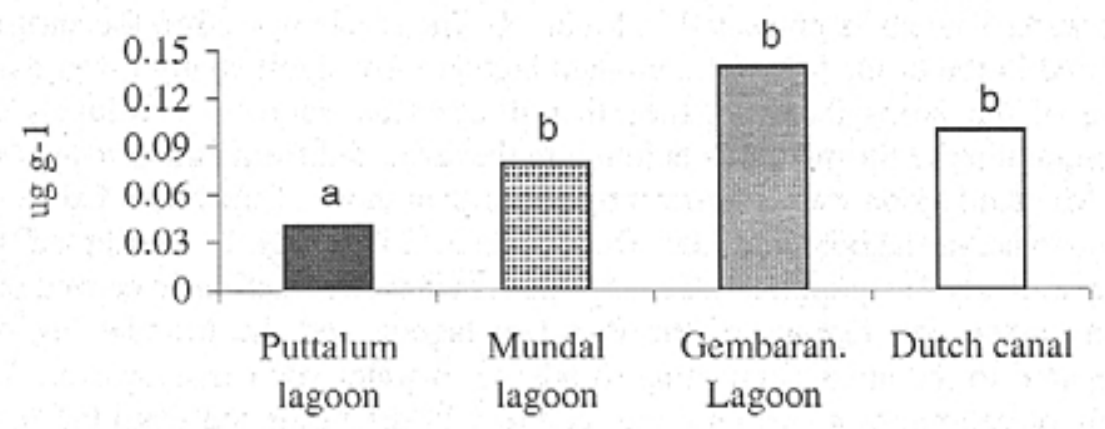

(ii) Chromium

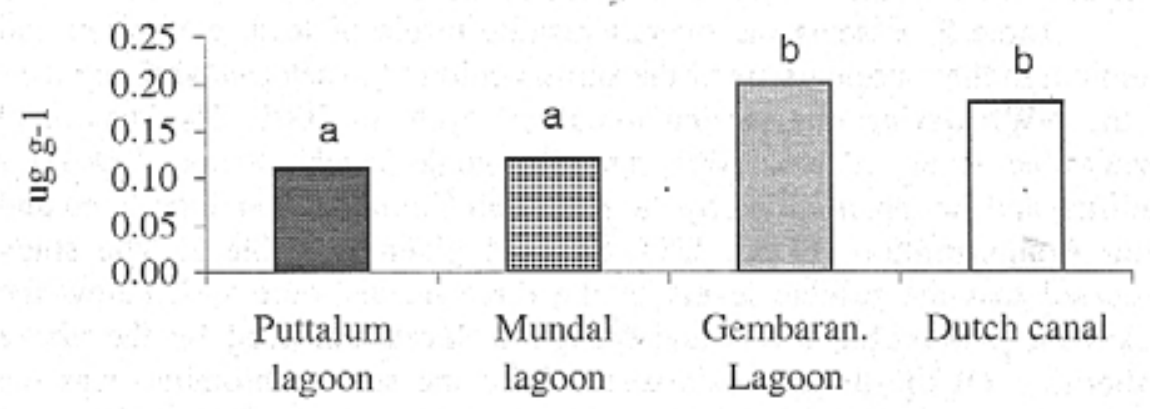

(iii) Cadmium

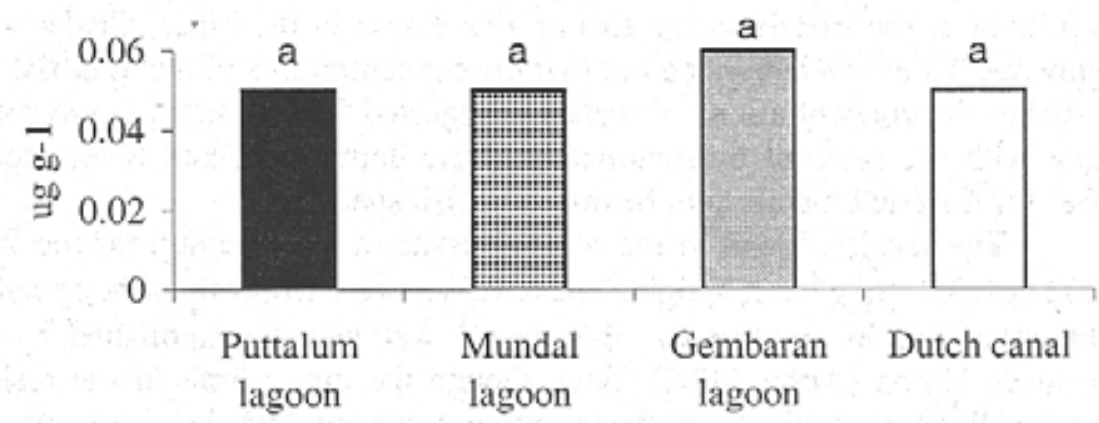

Figure 1. Water source-wise comparison of the levels of lead, cadmium and chromium in the muscle tissue of tiger shrimp, Penaeus monodon ( $\mu \mathrm{g} \mathrm{g}^{-}{ }^{-}$wet weight) cultured in the North Western Province of Sri Lanka. For each metal, bars with the same letter are not significantly different from each other (ANOVA, Tukey's test $\mathrm{P}<0.05$ ). Log transformed data were used for data analysis. 
Table 2: Residue levels of lead, chromium and cadmium in shrimp (Penaeus monodon) cultured in selected farms of the North Western Province, Sri Lanka and percentage of samples exceeding $25 \%, 50 \%$ and $75 \%$ of maximum permissible levels.

\begin{tabular}{|c|c|c|c|c|c|c|}
\hline \multirow[t]{2}{*}{ Metal } & \multirow[t]{2}{*}{$\begin{array}{l}\text { Residue level } \\
\text { ( } \mu \mathrm{g} \mathrm{g}^{\prime \prime} \text { wet wt) }\end{array}$} & \multirow{2}{*}{$\begin{array}{l}\text { MPL* } \\
\left(\mu g^{* 1}\right. \\
\text { wet wt) }\end{array}$} & \multirow{2}{*}{$\begin{array}{l}\text { Guide } \\
\text { level*k } \\
\left(\mu g^{* 1}\right. \\
\text { wet wt) }\end{array}$} & \multicolumn{3}{|c|}{$\begin{array}{l}\text { Percentage of samples } \\
\text { exceeding }\end{array}$} \\
\hline & & & & $\begin{array}{l}25 \% \\
\text { of } \\
\text { MPL }\end{array}$ & $\begin{array}{l}50 \% \\
\text { of } \\
\text { MPL }\end{array}$ & $\begin{array}{l}75 \% \\
\text { of } \\
\text { MPL }\end{array}$ \\
\hline Lead & $\begin{array}{l}0.096^{t} \pm 0.024 \\
(0.002-0.330)\end{array}$ & 0.50 & 3.00 & $14 \%$ & $3 \%$ & $0 \%$ \\
\hline Chromium & $\begin{array}{l}0.200^{\mathrm{C}} \pm 0.004 \\
(0.056-0.420)\end{array}$ & NA & 12.00 & - & - & - \\
\hline Cadmium & $\begin{array}{l}0.057^{2} \pm 0.004 \\
(0.017-0.092)\end{array}$ & 0.50 & 1.50 & $0 \%$ & $0 \%$ & $0 \%$ \\
\hline
\end{tabular}

Residue levels are presented as mean \pm standard error of the mean and the ranges $(n=360)$. Means not followed by the same superscript are significantly different from each other (ANOVA, Tukey's test, $\mathrm{p}<0.05$ ). Log transformed data were used for the statistical analysis. $\mathrm{NA}=$ Not available; MPL $=$ Maximum Permissible Level; *Anon. (2001); **Anon. (1996).

The chromium levels of the shrimp tissue were considerably higher than that of the other two metals and ranged from 0.056 to $0.420 \mu \mathrm{g} \mathrm{g}^{-1}$ wet weight. The overall mean of the chromium levels in the muscle tissue of $P$. monodon $\left(0.2 \mu \mathrm{g} \mathrm{g}^{-i}\right.$.wet weight) was nearly two times and three times higher than that of lead and cadmium levels respectively. However, the overall mean of chromium as well as the highest metal level in the shrimp tissue was well below the guide level of $12 \mu \mathrm{g} \mathrm{g}^{-1}$ wet weight in crustaceans and $13 \mu \mathrm{g} \mathrm{g}^{-1}$ wet weight in molluscan bivalves in the FDA guidelines for fish and fishery products (Anon. 1996).

Present study revealed that the cadmium levels in the muscle tissue of the cultured $P$ monodon ranged from 0.017 to $0.092 \mu \mathrm{g} \mathrm{g}^{-1}$ wet weight. The overall mean of cadmium level $\left(0.057 \mu \mathrm{g} \mathrm{g}^{-1}\right.$ wet weight $)$ and even the highest cadmium level $\left(0.092 \mu \mathrm{g} \mathrm{g}^{-1}\right.$ wet weight $)$ in shrimp tissue did not exceed the maximum permissible level in crustaceans, $0.5 \mu \mathrm{g} \mathrm{g}^{-1}$ wet weight in the EU standards and the guide level, $3.0 \mu \mathrm{g} \mathrm{g}^{-1}$ wet weight in crustaceans and $4.0 \mu \mathrm{g} \mathrm{g}^{-1}$ wet weight in molluscan bivalves in the FDA guidelines (Anon. 1996; Anon. 2001).

The highest residue level of chromium $\left(0.420 \mu \mathrm{g} \mathrm{g}^{-1}\right.$ wet weight) found in shrimp monitored in the present study was 30 fold lower than the guide level of chromium (12 $\mu \mathrm{g} \mathrm{g}^{-1}$ wet weight) established for crustaceans by the FDA guidelines (Anon. 1996). The highest residue level of lead in 
shrimp was $0.330 \mu \mathrm{g} \mathrm{g}^{-1}$ wet weight which was 1.5 fold lower than the maximum permissible level $\left(0.5 \mu \mathrm{g} \mathrm{g}^{-1}\right.$ wet weight) in the EU guidelines and 5 fold lower than the guide level $\left(1.5 \mu \mathrm{g} \mathrm{g}^{-1}\right.$ wet weight) in FDA specifications. The upper limit of residue level of cadmium $\left(0.092 \mu \mathrm{g} \mathrm{g}^{-1}\right.$ wet weight) was 5 fold lower than the maximum permissible level $\left(0.5 \mu \mathrm{g} \mathrm{g}{ }^{-1}\right.$ wet weight) in crustaceans recommended for human consumption.

Of the total shrimp samples analyzed, only $14 \%$ of the samples exceeded $25 \%$ of the maximum permissible level (MPL) established for Lead $\left(0.5 \mu \mathrm{g} \mathrm{g}^{-1}\right.$ wet weight) by the EU and $3 \%$ of the analyzed samples exceeded $50 \%$ of the maximum permissible level and the lead content in all the samples were below $75 \%$ of the MPL (Table 3). For cadmium, recorded metal levels for all the analyzed samples were less than $25 \%$ of the maximum permissible levels.

Petersen \& Mortensen (1994) showed that the mean levels of lead, chromium and cadmium in the muscle tissue of shrimp in Denmark were (in $\mu \mathrm{g} \mathrm{g}^{-1}$ wet weight) $0.050,0.021$ and 0.026 respectively which were also close to the values reported from the shrimp in the present study. The levels of the three metals in the shrimp were well below the established Danish action levels for human consumption.

\section{Conclusion}

None of the three metals, i.e., lead, chromium or cadmium in the muscle tissue of the sampled shrimp exceeded the guide levels or maximum permissible levels established by the competent authorities under fish export regulations. It can be concluded that the shrimp $P$. monodon cultured in the farms fed from the four selected water sources are safe for human consumption in relation to the current residue levels of these three elements. However, there should be a constant monitoring program on the residue levels of these toxic metals in the cultured shrimp because there is a tendency to reach the maximum permissible levels of these metals in shrimp with the increasing urbanization and agricultural and the industrial development in the area.

\section{Acknowledgements}

Scholarship awarded to the first author by the ADB Science and Technology Personnel Development Project and financial assistance by National Aquatic Resources Research \& Development Agency are gratefully acknowledged.

\section{References}

Abou-Arab, A.A.K., A.M. Ayesh, H.A. Amra \& K. Naguib 1996.

Characteristic levels of some pesticides and heavy metals in imported fish, Food Chemistry 57 (4): 487-492. 
Anonymous 1996.

Environmental Chemical Contaminants and Pesticides. Fish and Fishery Products Hazards and Controls Guide, Department of Health and Human Services, Public Health Service, Food and Drug Administration, Center for Food Safety and Applied Nutrition, Office of Seafood, Washington, DC.

Anonymous 2001.

Setting maximum levels for certain contaminants in foodstuffs. Official Journal of European Communities, L77/1-L77/13.

Corea, A., J. Johnstone, J. Jayasinghe, S. Ekarathne \& K. Jayawardhena 1998.

Self-pollution: A major threat to the prawn farming industry in Sri Lanka, Ambio 27 (8): 662-668.

Garbarino, J.R., R C. Antweiler, T.I. Brinton, D.A. Roth \& H.E. Taylor 1995. Heavy metals in the Mississippi River. US Geological Survey Circular, No. 1113, (R. H. Meade, ed.), Reston, Verginia.

Heiny, J.S. \& C.M. Tate 1997.

Concentrations, distribution and comparison of selected trace elements in bed sediment and fish tissue in the South Platte River Basin, USA, 1992-1993, Archives of Environmental Contamination and Toxicology 32: 246-259.

Jorhem, L. 1993.

Determination of metals in foodstuffs by atomic absorption spectrosphotometry after dry ashing: NMKL inter-laboratory study of lead, cadmium, zinc, copper, iron, chromium and nickel. Journal of AOAC International 76 (4): 798-813.

Petersen, A. \& G K. Mortensen 1994.

Trace elements in shellfish on the Danish market. Food Additives and Contaminants 11 (3): 365-373.

Rao, L.M., S. Vani \& K. Ramneswari 1998.

Metal accumulation in tissues of Macrobrachium rude from Mehadrigedda stream, Vissakhapathnam. Pollution Research 17 (2): 137-140.

Solis, N.B. 1988.

Biology' and Ecology. In: Biology and Culture of Penaeus monodon, pp. 1-36, South East Asian Fisheries Development Committee (SEAFDEC), Phillipines.

Storelli, M.M. \& G.O. Marcotrigiano 1999.

Cadmium and total mercury in some cephalopods from the South Adriatic Sea (Italy). Food Additives and Contaminants 16 (6): 261265. 